\title{
Perancangan Sistem Informasi Penilaian Siswa Berbasis Web Pada SMK Al-Ayaniah
}

\author{
Arsi yulianjani*1, Nurlaila Suci Rahayu Rais ${ }^{2}$, Viviet Andriana ${ }^{3}$ \\ ${ }^{1,2}$ Program Studi Manajemen Informatika Universitas Raharja \\ ${ }^{1}$ Program Studi Sistem Informasi Universitas Raharja \\ Email : ${ }^{1 *}$ arsiyulianjani@raharja.info, ${ }^{2}$ nurlaila@,raharja.info, ${ }^{3}$ viviet@,raharja.info
}

\begin{abstract}
Abstrak
Teknologi Informasi saat ini berkembang sangat pesat. Di kantor, sekolah, perusahaan, pusat perbelanjaan, pusat pemerintahaan dan lain-lain, semuanya sudah serba komputer. Dengan adanya perkembangan teknologi informasi dapat membantu dan mempermudah manusia dalam melakukan pekerjaan, tugas, dan kepentingannya. Demikian pula dengan SMK Al-Ayaniah, sekolah ini membutuhkan sistem pengolahan nilai yang terkomputerisasi, untuk membantu tugas guru dan wali kelas pada sekolah tersebut. Saat ini pengolahan data penilaian siswa-siswi SMK Al-Ayaniah masih semi komputer, yaitu masih terbatas pada penggunaan Microsoft Excel. Dalam satu kelas masing-masing siswa memiliki nilai yang berbeda-beda dan dicatat di buku, sehingga membutuhkan waktu yang sangat lama dalam pengerjaannya. Penelitian ini bertujuan menggunakan sistem berbasis web pada SMK Al-ayaniah untuk mempermudah penilaian. Untuk penganalisaan sistem digunakan metode SWOT (Strength, Weakness, Opportunities, Threats) dan untuk perancangan modelnya digunakan metode UML (Unified Modelling Language) untuk Bahasa pemrogramannya menggunakan PHP yang menggunakan aplikasi Sublime serta dalam pembuatan database nya menggunakan MySQL. Dan untuk pengujian hasil rancangan digunakan Black Box testing. Dengan adanya sistem pengolahan nilai secara terkomputerisasi dapat membantu guru dan wali kelas dalam menginput dan mengolah nilai siswa dan siswi SMK Al-ayaniah lebih efektif dan efisien.
\end{abstract}

Kata Kata Kunci : Sistem, nilai, siswa

\begin{abstract}
In the current era, the advance of Information Technology is growing rapidly. Even in daily life, everything is computerized, such as in offices, schools, companies, shopping centers, government centers and many more. By the development of information technology can help and facilitate humans in doing their jobs, tasks and interests. Similarly, SMK Al-Ayaniah, this school needs a computerized value-processing system, to help teachers and parents work in the school. Currently, the processing of assessment data of SMK AlAyaniah is still semi-computer, which is still limited to the use of Microsoft Excel. In one class each student has different grades and recorded in a book, so it requires a very long time in the process. The purpose of this study is to facilitate the assessment using a web-based system at Al-ayaniah Vocational School. The method used to analyze this system is the SWOT method (Strength, Weakness, Opportunities, Threats) and for the method of designing the model using UML (Unified Modeling Language) for programming languages using PHP that uses Sublime applications and in making its database using MySQL. And for testing the design using Black Box testing. With a computerized value processing system can help teachers and homeroom teachers in inputting and processing the grades of SMK Al-Ayaniah students more effectively and efficiently.
\end{abstract}

Keywords: System, grades, students 


\section{PENDAHULUAN}

Teknologi komputer dan jaringan komunikasi data yang maju pesat, membuat masyarakat dunia mudah dalam memanfaatkan dan menikmati internet begitu juga dengan masyarakat Indonesia. Pemakaian internet saat ini sudah diaplikasikan pada tiap-tiap bentuk kehidupan dan tidak sedikit perubahan yang telah terjadi, salah satu perubahan yang sangat berpengaruh adalah Lembaga pendidikan. Sekolah merupakan satu contoh lembaga pendidikan yang terkena dampak dari kemajuan teknologi komputer.

Aris, Dkk dalam jurnalnya (2016), mendefinisikan perancangan ialah menggambarkan, merencanakan, membuat sketsa dan juga mengatur elemen-elemen terpisah menjadi satu kesatuan yang utuh sehingga dapat difungsikan. Gatoet dalam Maimunah dkk (2017: 4.6-38), menyebutkan bahwa rancangan haruslah dapat berfungsi dengan baik sehingga kebutuhan pengguna dapat terpenuhi dan berguna untuk manusia dalam kehidupannya di dunia untuk mempertahankan dan mengembangkan hidup.

Oleh soleh dkk berpendapat dalam jurnal Semnasteknomedia Vol.6 No.1 (2018:128) bahwa sistem merupakan beberapa rangkaian komponen yang saling terkait dan berinteraksi dan tidak dapat dipisahkan untuk mencapai suatu tujuan. Sistem terdiri dari beberapa subsistem, dimana subsistem ini untuk mendukung sistem besar. Berdasarkan pendapat-pendapat ahli diatas, maka dapat disimpulkan bahwa: Perancangan adalah suatu penggambaran sebuah perencanaan yang berisikan elemen-elemen yang diterapkan menjadi satu kesatuan sistem yang utuh yang dapat difungsikan dan diimplementasikan.

Menurut Anwar, N. (2015) menyebutkan bahwa penilaian adalah pengumpulan informasi (angka atau deskripsi verbal), analisis, dan interpretasi melalui proses sistematis untuk mengambil keputusan. Arikunto juga berpendapat dalam jurnal Sasomo (2015), sebuah proses pengumpulan data atau informasi yang digunakan untuk menentukan ketercapaian tujuan pendidikan dan untuk mengambil keputusan dengan menggunakan bermacam cara dan alat dinamakan penilaian. Dari 2 (dua) asumsi ahli di atas, maka dapat dikatakan bahwa penilaian adalah suatu kegiatan pengumpulan data dan informasi untuk mengambil suatu keputusan.

Teknologi pada sekolah-sekolah biasanya digunakan untuk pendataan siswa, mulai dari absensi, pendaftaran sekolah sampai dengan penginputan nilai. Namun demikian, terkadang sekolah masih menggunakan sistem pencatatan tangan dalam penginputan nilai, sehingga membutuhkan waktu yang tidak sedikit dalam pengerjaannya. Seperti yang terjadi pada SMK Al-ayaniah yang masih semi komputer untuk pengerjaan penginputan nilai. Penginputan nilai dilakukan oleh petugas dengan menerima berkas nilai yang diberikan oleh guru mata pelajaran, kemudian dicatat/di input menggunakan Excel dan dikumpulkan di buku penilaian. Setelah itu disalin/ dimasukkan ke dalam buku laporan (raport) lalu dibagikan kepada wali murid/ siswa. Hal tersebut sangat mengkhawatirkan, sebab dapat mengakibatkan kerusakan, basah bahkan kehilangan pada buku raport tersebut yang disebabkan oleh kecerobohan atau ketidak pedulian dari wali murid/ siswa. Untuk alasan tersebut, SMK Al-ayaniah membutuhkan sistem penilaian yang cepat dan akurat sehingga mempermudah proses penilaian.

Seperti yang disebut di atas, SMK Al-ayaniah masih semi komputer dalam penginputan nilai siswa dan belum mempunyai database untuk menyimpan data nilai siswa. Selain itu dibutuhkan ketelitian yang tinggi untuk memproses dan mengolah nilai siswa, sehingga nilai tidak dapat di segera diinformasikan kepada siswa. Oleh karena itu, SMK Al-Ayaniah memerlukan sistem informasi berbasis web untuk mengolah data tersebut. Data-data nilai siswa yang dimasukkan oleh wali kelas secara otomatis akan tersimpan didalam database dan siswa yang ingin mengetahui informasi nilai ujian tengah semester dan ujian akhir semester mereka dapat mengaksesnya secara online. Dengan adanya sistem informasi ini diharapkan akan mempermudah wali kelas dalam mengolah data nilai.

Berdasarkan latar belakang masalah diatas, dapat ditarik beberapa rumusan permasalahan sebagai berikut:

1. Bagaimana sistem penilaian siswa yang berjalan pada SMK Al-Ayaniah ?

2. Bagaimana kendala dan permasalahan yang dihadapi pada sistem penilaian siswa yang berjalan pada SMK Al-Ayaniah?

3. Bagaimana merancang sistem informasi penilaian siswa berbasis web untuk mempermudahkan Wali kelas, guru dan siswa? 


\section{Literature Review}

1. Penelitian yang dilakukan oleh Nur Azizah, Sri Rahayu \& Nova Adhista (2017) yang berjudul “ Perancangan Sistem Informasi Penilaian Kinerja Karyawan SPG Berstatus Kontrak Pada PT. SOFTEX INDONESIA Menggunakan Metode Simple Additive Weighting (SAW)“. Pada bagian pemasaran PT SOFTEX Indonesia, terdapat SPG (Sales Promotion Girl), yaitu bagian yang berhubungan langsung dengan konsumen, karena bagian ini bertugas sebagai penjual produk. Status mereka sebagai karyawan kontrak, tetapi akan dapat diangkat menjadi karyawan tetap apabila telah memenuhi kriteria yang diatur oleh perusahaan. Namun, penilaian kinerja karyawan SPG yang ada saat ini masih belum efektif sehingga seringkali penilaian tidak akurat. Oleh karenanya, perusahaan sering salah memilih karyawan karena tidak sesuai dengan harapan dan kriteria yang dibutuhkan. Untuk mengatasi permasalahan tersebut, PT SOFTEX Indonesia membutuhkan sistem yang terkomputerisasi untuk menghitung dan menilai karyawan SPG yang memenuhi kriteria penilaian karyawan tetap dengan menggunakan metode Simple Additive Weighting (SAW). Metode yang digunakan untuk mengumpulkan data: observasi, wawancara dan studi pustaka. Pembuatan sistem perangkat lunak menggunakan Unified Modelling Language (UML). Bahasa pemrograman menggunakan PHP dan menggunakan MySQL untuk database. Hasil yang didapatkan dari penelitian ini adalah sebuah aplikasi Sistem Penilaian Kinerja SPG yang efektif dan akurat.

2. Penelitian yang dilakukan oleh Quratul Aini \& Dkk. Vol. 4 No. 1 (2018). Membahas tentang Ketepatan waktu atau on time dalam proses penginputan nilai. Hal ini sangat penting agar mahasiswa dapat dengan cepat menerima nilai. Namun konsep gamifikasi yang saat ini digunakan masih kurang menarik, karena masih terdapat 3 (tiga) faktor penyebabnya. Pertama, dosen lambat dalam menginput nilai dari batas waktu yang ditentukan. Kedua, motivasi yang kurang terhadap dosen untuk menginput nilai secara ontime, hal ini dapat menurunkan kinerja dosen karena mahasiswa akan mengalami keterlambatan dalam menerima dan melihat nilai. Ketiga, untuk memotivasi dosen diperlukan adanya apresiasi terhadap dosen yang telah menginput nilai tepat waktu (on time). Untuk itu, dalam penelitian ini dilakukan beberapa pemecahan masalah yaitu: Pertama, agar kinerja dosen menjadi efektif dan efisien dilakukan pengembangan gamifikasi pada PEN+. Kedua, pemberian trophy untuk dosen yang masuk dalam 10 (sepuluh) besar rank gamifikasi PEN+. Ketiga, setiap dosen yang masuk dalam 10 (sepuluh) besar ranking gamifikasi diberikan 1 (satu) trophy. Pada penelitian ini, digunakan metode pengumpulan data, pengembangan sistem, analisa sistem, perancangan, dan pengujian, untuk memperoleh data dalam menerapkan gamifikasi $\mathrm{PEN}+$. Berikut beberapa keuntungan yang didapatkan dalam pengembangan gamifikasi $\mathrm{PEN}+$, yaitu: mahasiswa dapat melihat nilai dengan cepat; memberikan motivasi kepada dosen dalam proses penginputan nilai; dapat menjaga kedisiplinan dosen sehingga dapat meningkatkan mutu dosen.

3. Penelitian yang dilakukan oleh Nizar Haris, Khairul Imtihan \& Maulana Ashari. Vol 1 No. 2 (2018) yang berjudul "PERANCANGAN SISTEM INFORMASI PENGOLAHAN DATA NILAI SISWA BERBASIS WEB DI SMKN 1 PRAYA". Penelitian ini menghasilkan sistem informasi untuk mengolah data nilai siswa di SMKN 1 PRAYA, dengan menggunakan media komputer yang mempermudah dalam pencatatan data nilai siswa dan menjadikan media efektif untuk perkembangan pendidikan di SMKN 1 PRAYA, sehingga pengolahan data nilai siswa dapat diproses dengan cepat secara otomatis.

4. Penelitian yang dilakukan oleh Dendy Jonas, Endang Sunandar \& Satrio Pramudito Sohir. (2018) yang berjudul "RANCANG BANGUN SISTEM INFORMASI PENILAIAN SISWA PADA SMA NEGERI 9 KOTA TANGERANG". Membahas tentang pencatatan dan penyimpan nilai yang masih sangat manual. Penelitian ini bertujuan untuk membuat sistem informasi penilaian siswa berbasis web pada SMAN 9 kota Tangerang. Adapun beberapa metode yang digunakan dalam penelitian ini yaitu: metode pengumpulan data; metode analisa; dan metode perancangan. Metode pengumpulan data dilakukan dengan mengadakan observasi di sekolah, melakukan dokumentasi 
dengan mempelajari dokumen yang ada, melakukan wawancara dengan di pihak terkait. Metode analisa sistem menggunakan Unified Modelling Language ( UML ) yang digambarkan oleh use case diagram, activity diagram dan sequence diagram. Metode perancangan Metode perancangan menggunakan Unified Modelling Language (UML) dan menggunakan bahasa pemrograman PHP ( PHP Hypertext Preprocessor). Penelitian ini menghasilkan rancang bangun sistem informasi penilaian siswa yang dapat memudahkan user dalam menginput dan membuat laporan nilai siswa.

5. Penelitian yang dilakukan oleh Ignatius Joko Dewanto (2016) yang berjudul"MembangunSistem Penunjang Keputusan Untuk Investasi Saham Dengan Metode Simple Additive Weighting (SAW)".Kesimpulan dari penelitian ini adalah penerapan metode SAW dalam mendeskripsikan investasi saham sesuai dengan unit kinerja saham yang dimiliki di setiap perusahaan untuk mengambil keputusan. Aplikasi sistem penunjang keputusan dengan sistem perhitungan yang baku dalam melakukan penilaian investasi saham dapat menampilkan hasil perbandingan dari setiap saham-saham yang akan direkomendasikan untuk penentuan pemilihan saham dan digunakan sebagai alat pendukung keputusan seorang pialang dalam berinvestasi

\section{METODE PENELITIAN}

Metode Analisis SWOT dilakukan guna mengenali kekuatan (Strength), kelemahan (weakness), peluang (opportunities) dan ancaman (threats). Analisa SWOT Strengths) Weakness (W) - Tersedianya tenaga ahli dan teknisi untuk memantau sistem atau program agar berjalan dengan baik pada SMK Al-ayaniah . Informasi nilai ujian dilakukan masih menggunakan surat · menggunakan kertas yang berlebih dan kertas dapat mudah rusak/hilang - penyampaian Informasi/data nilai ujian yang didapat tidak tepat waktu Opportunities (O) Threats ( $\mathrm{T}$ ) · Memanfaatkan sistem untuk memudahkan guru dalam menginput data nilai dan menyampaikan informasi melalui meminimalkan penggunaan kertas $\cdot$ hilangnya data karena terhapus oleh user. · Rusaknya hardisk pada komputer. · Adanya virus dan ancaman cracker dari luar.

\section{HASIL DAN PEMBAHASAN}

Prosedur sistem berjalan pada SMK Al-ayaniah sebagai berikut:
a. Siswa Melakukan Ujian (Ulangan Harian .UTS, UAS)
b. Guru Mengoreksi Hasil Ujian siswa, kemudian memberikan penilaian
c. kepada siswa yang telah melakukan ujian dan merekap nilai ujian.
d. Guru memberikan hasil rekap nilai kepada wali kelas
e. Wali kelas menerima rekap nilai
f. Wali kelas membuat raport nilai

Untuk menganalisa sistem berjalan pada SMK Al-ayaniah digunakan Visual Paradigm for UML (Unified Modelling Language). 


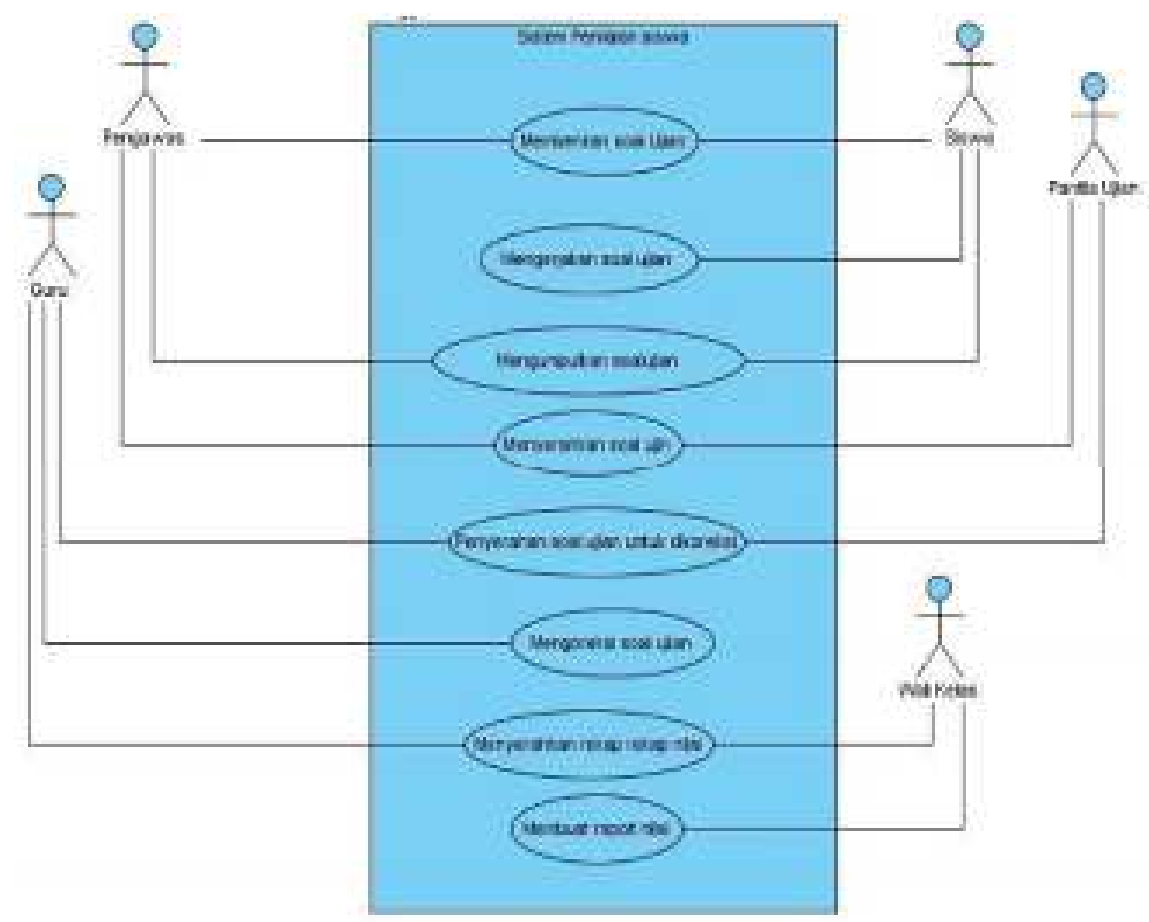

Gambar 1. Use Case Diagram

Use case Diagram yang berjalan di atas terdapat :

1. 1 sistem yang mencangkup semua kegiatan penilaian

2. 5 aktor yang melakukan kegiatan adalah pengawas, siswa,Panitia ujian,guru, wali kelas

3. 8 use case yang dilakukan oleh aktor-aktor yaitu memberikan soal ujian,mengerjakan soal ujian, mengumpulkan soal ujian, menyerahkan soal ujian, penyerahan soal ujian untuk dikoreksi, mengoreksi soal ujian, membuat rekap nilai,menyerahkan rekap nilai, membuat raport nilai.

\section{IMPLEMENTASI}

Tampilan sistem penilaian siswa yang memiliki berbagai fitur yang digunakan untuk menampilkan dan menginput semua kegiatan penilaian siswa:

1. Menu Login
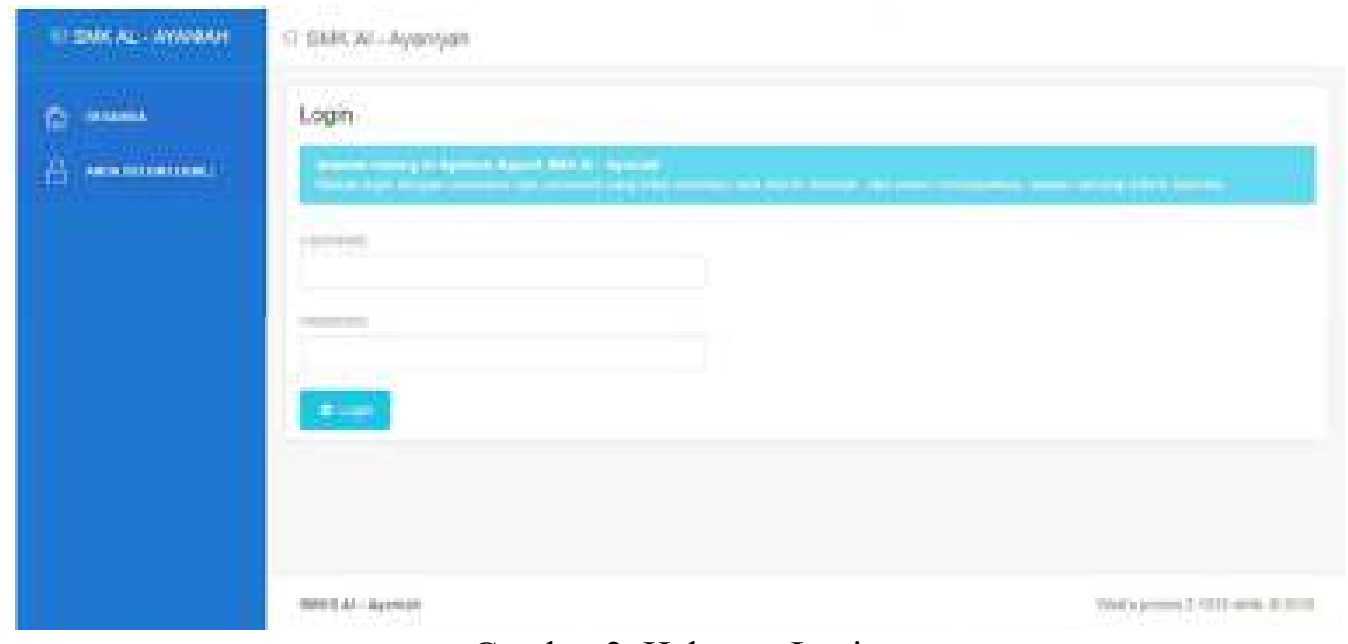

Gambar 2. Halaman Login 
Pada gambar 1 Guru memasukan username dan password yang sebelumnya telah didaftarkan pada website 2. Tampilan Input Data Guru

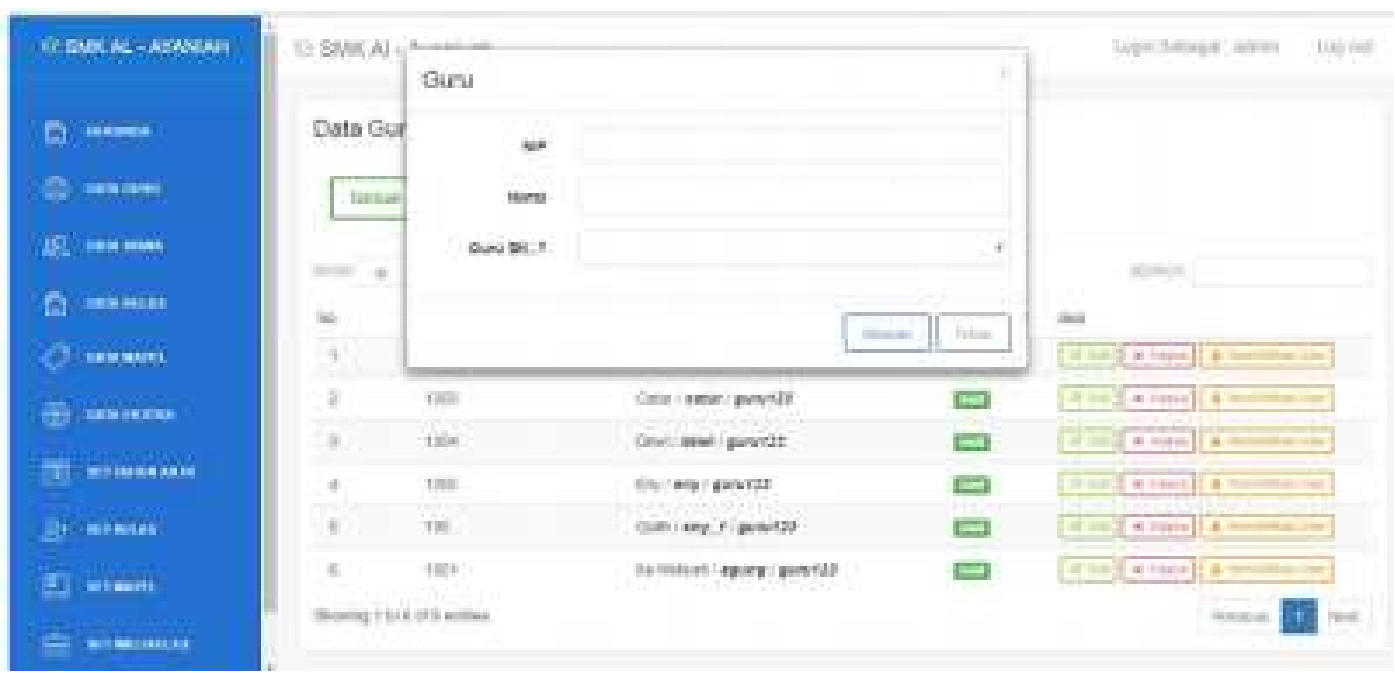

Gambar 3. Tampilan Input Data Guru

Pada gambar 2 tampilan input data guru, guru dapat menginput data sesuai bidangnya Tampilan Input Data Siswa

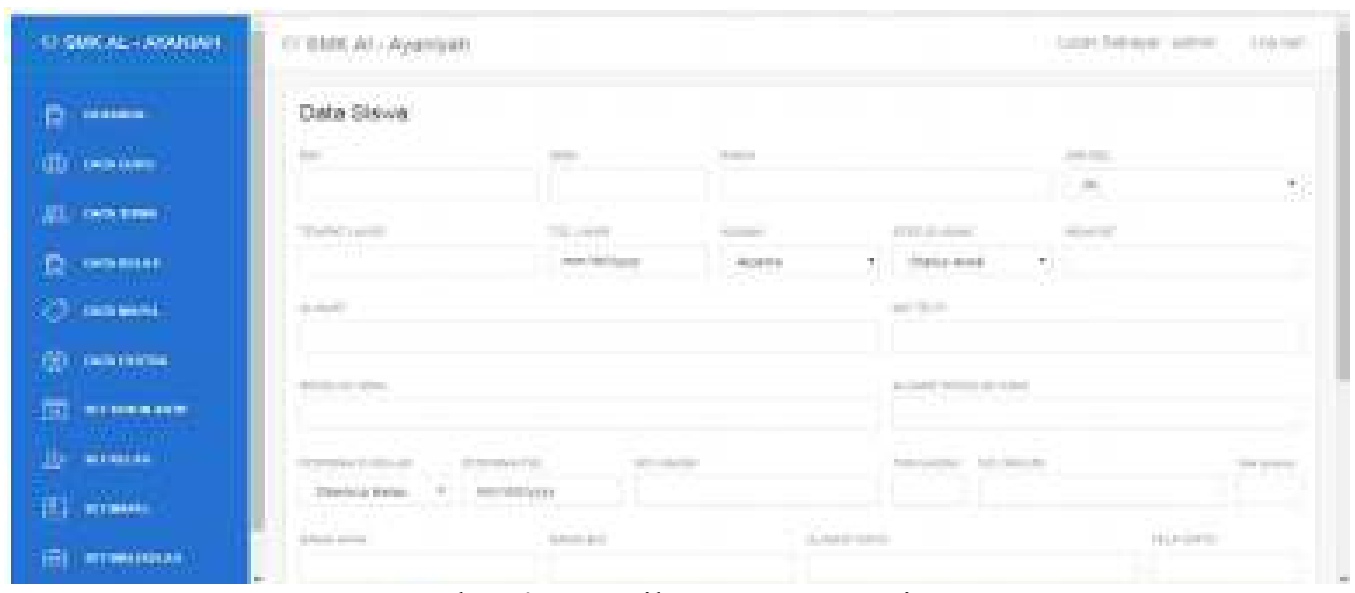

Gambar 4. Tampilan Input Data Siswa

Pada gambar 3 tampilan data siswa, guru dapat menginput data siswa sesuai dengan data yang diberikan oleh siswa 
3. Input Data Kelas

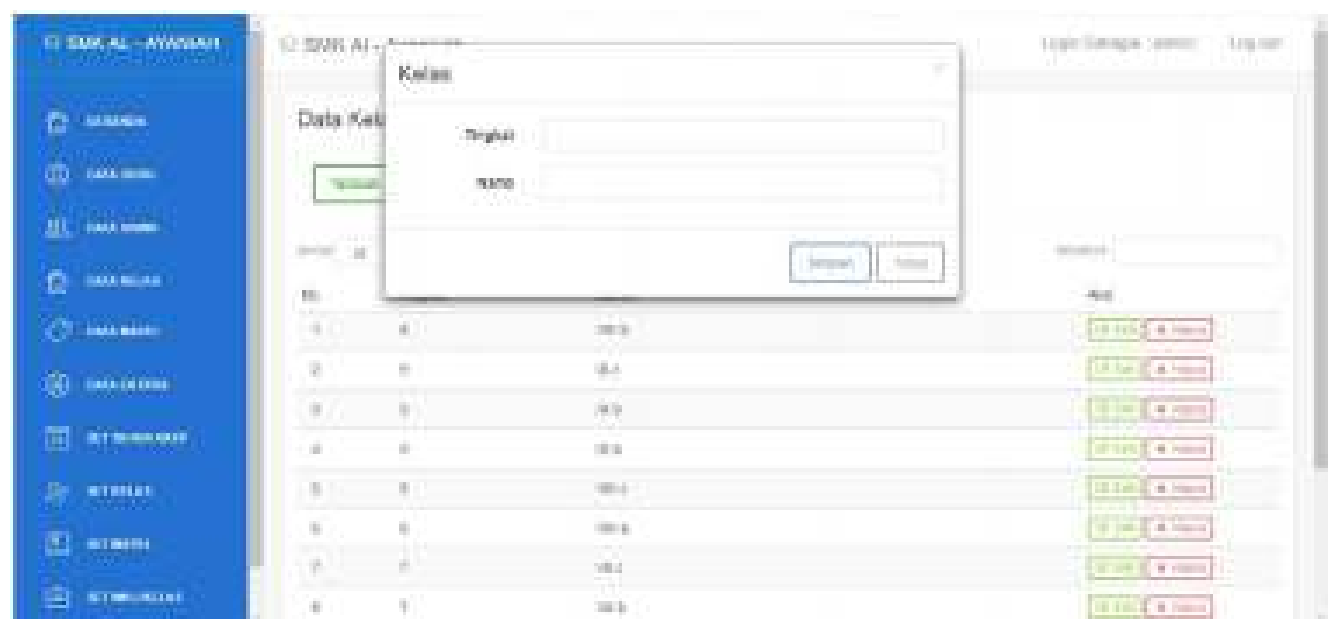

Gambar 5. Tampilan Input Data Kelas

Pada gambar 4 tampilan input data kelas, guru dapat menginput siswa sesuai dengan tingkat kelasnya

4. Tampilan Mata Pelajaran

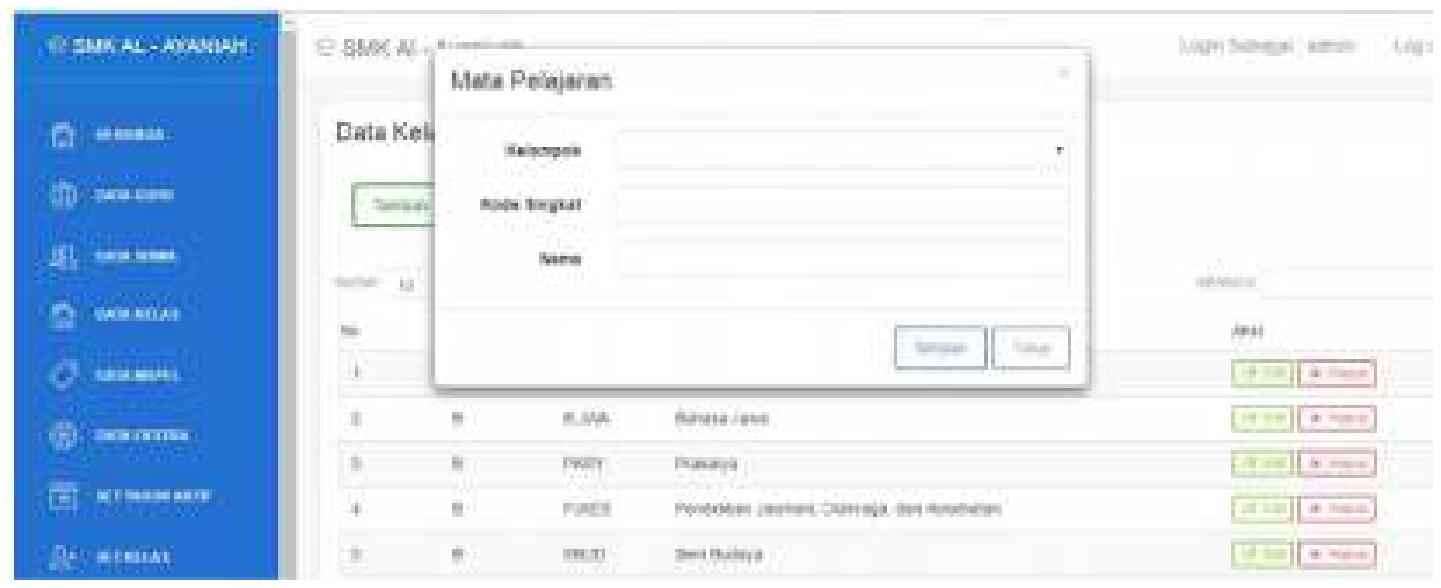

Gambar 6. Tampilan Input Mata Pelajaran

Pada gambar 5 tampilan input mata pelajaran, guru dapat menginput siswa di sesuaikan dengan mata pelajaran (kelompok,kode singkat dan nama) 
5. Tampilan Periode Aktif

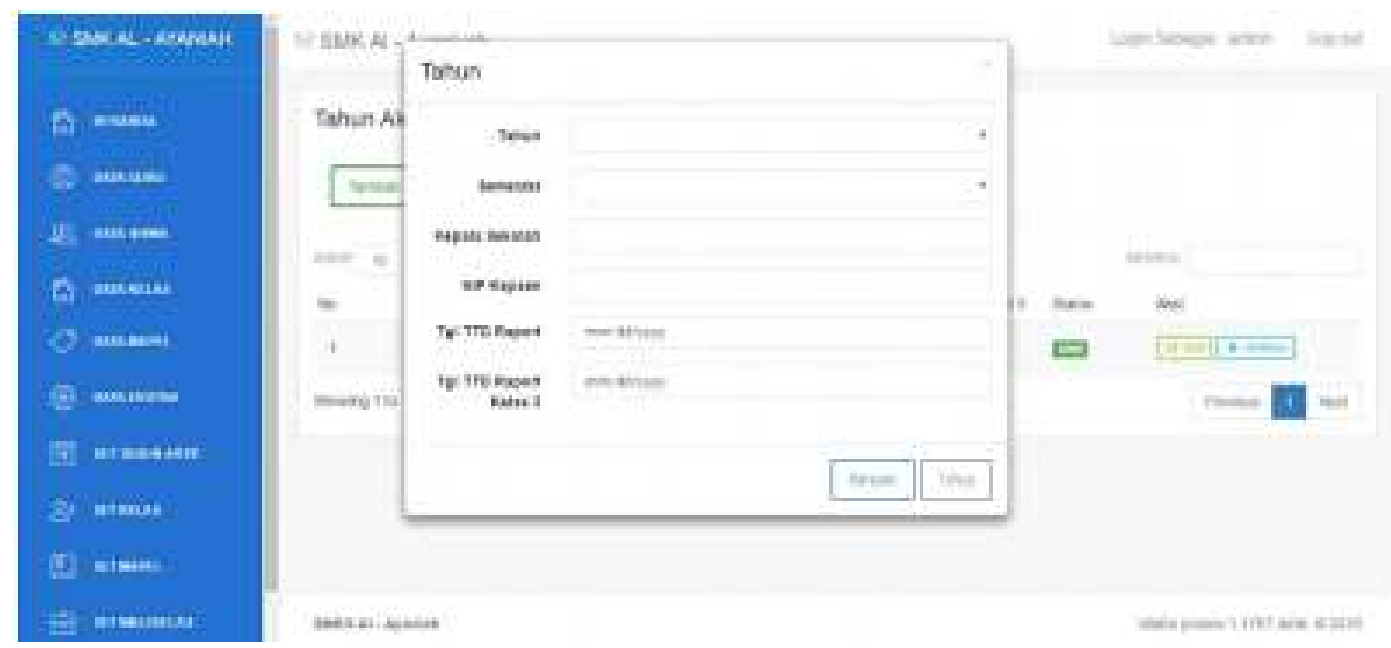

Gambar 7. Tampilan Periode Aktif

Pada gambar 6 tampilan periode aktif, guru dapat menginput siswa periode aktif disesuaikan dengan tahun masa aktif siswa

\section{KESIMPULAN}

1. Kelebihan dari sistem yang diusulkan bila dibandingkan dengan sistem yang sedang berjalan pada smk Al-ayaniah proses pengolahan nilai berbasis web. menggunakan komputer sebagai alat bantunya, sehingga pengolahan data pada sistem informasi pengolahan data nilai dapat dilakukan dengan mudah, cepat, dan data yang diolah menjadi lebih akurat dan efisien.

2. Perancangan sistem informasi pengolahan data nilai berbasis web ini dapat menjadi solusi bagi para guru dalam mengolah data nilai yang sebelumnya manual menjadi terkomputerisasi serta menjadi sarana yang tepat dalam mengembangkannya menjadi sistem informasi berbasis web.

3. Dengan adanya sistem informasi pengolahan data nilai siswa ini maka proses penilaian dapat berjalan dengan baik

\section{SARAN}

1. Sistem penilaian siswa yang diusulkan perlu adanya pengembangan yang dapat menampilkan notifications yang masuk kedalam sistem sebagai informasi kepada siswa bahwa nilai raport sudah bisa dilihat di sistem.

2. Perlu diperhatikan dilakukan evaluasi secara berkala terhadap sistem tersebut untuk selanjutnya diadakan perbaikan sesuai perubahan dan perkembangan pada SMK Al-ayaniah.

3. Sebaiknya didukung oleh perangkat yang memadai, baik dari segi peralatannya (software dan hardware) maupun sumber daya manusia agar sistem dapat berjalan secara maksimal. 


\section{DAFTAR PUSTAKA}

[1]. Aris, Dini Andriani, Eka Sari Dian, \& Apriyani Romodor. (2016). Perancangan Aplikasi Sistem Informasi Penjualan Tiket pada PT Nur Rizky Pratama Travel Berbasis Web". Seminar Nasional Teknologi Informasi dan Multimedia 2016, Vol 4 No 1, ISSN : 2302-3805.

[2]. Maimunah; Dini Luigi; Ade Ferdiansyah;. (2017). "Rancang Bangun Sistem Pelayanan Data Pelanggan (XIBAR) Berbasis Online". Seminar Nasional Teknologi Informasi dan Multimedia 2017, Vol 5 No 1, ISSN : 2302 - 3805.

[3]. soleh, o. d. (2018). Jurnal Semnasteknomedia. Aplikasi Monitoring Jumlah Bibit Tanaman Menggunakan Analisa Balance ScoreCard pada UPTD TPA Rawa Kucing Kota Tangerang.

[4]. Anwar, N. (2015). Penilaian Hasil Belajar. Penilaian Hasil Belajar. Diambil dari Kompetensi Profesional Penilaian Hasil Belajar.

[5]. Sasomo, B. (2017). Pendekatan Saintifik Dengan Metode Role Playing Mempermudah Penilaian Individu Peserta Didik. Inspiramatika.

[6]. Azizah,Nur. Rahayu, Sri \& Adhista,Nova. (2017). "Perancangan Sistem Informasi Penilaian Kinerja Karyawan SPG Berstatus Kontrak Pada PT. SOFTEX INDONESIA Menggunakan Metode Simple Additive Weighting (SAW)“. SENSI JOURNAL.Vol.3 No.2-Agustus. ISSN: 2461-1409.

[7]. Aini, Qurotul., Rahardja, Untung., Moeins, Anoesyirwan., \& Mariana Apriani, Dewi. (2018) Penerapan Gamifikasi Pada Sistem Informasi Penilaian Ujian Mahasiswa Untuk Meningkatkan Kinerja Dosen. JURNAL INFORMATIKA UPGRIS Vol. 4, No. 1, P/E-ISSN: 2460-4801/24476645 .

[8]. Haris, Nizae., Imtihan, Khairul., \& Ashari, Maulana. (2018). PERANCANGAN SISTEM INFORMASI PENGOLAHAN DATA NILAI SISWA BERBASIS WEB DI SMKN 1 PRAYA. Jurnal Manajemen Informatika \& Sistem Informasi - Volume 1 No 2 - 2018 E-ISSN : 2614-1701/ 2614-3739

[9]. Jonas, Dendy., Sunandar, Endang., \& Sohir, Satrio Pramudito. (2018). RANCANG BANGUN SISTEM INFORMASI PENILAIAN SISWA PADA SMA NEGERI 9 KOTA TANGERANG. SENSI Journal. Vol.4 No.2 - Agustus. ISSN : 2356-5195

[10]. Dewanto, Joko, Ignatius, Arrozi, MF.(2016) yang berjudul"Membangun Sistem Penunjang Keputusan Untuk Investasi Saham Dengan Metode Simple Additive Weighting (SAW)"SRITI 2016, Jakarta 